\title{
Subsurface nitrate reduction under wetlands takes place in
} narrow superficial zones

\author{
D Ribas $^{1,2}$, M Calderer $^{1 *}$, V Marti ${ }^{1,2}$, AR Johnsen $^{3}$, J Aamand $^{3}$, B Nilsson ${ }^{3}$, \\ JK Jensen ${ }^{3,4}$, P Engesgaard ${ }^{5}$ and C Morici ${ }^{6}$ \\ ${ }^{1}$ CTM Technological Centre, Pl. de la Ciència, 2, 08243 Manresa, Spain. \\ *Corresponding author: montse.calderer@ctm.com.es +34 938777373 \\ ${ }^{2}$ Department of Chemical Engineering, Technical University of Catalonia (UPC), ETSEIB, Av. Diagonal, 647, E-08028, \\ Barcelona, Spain. \\ ${ }^{3}$ Geological Survey of Denmark and Greenland (GEUS), Department of Geochemistry, ØsterVoldgade 10, DK-1350 \\ Copenhagen K, Denmark. \\ ${ }_{5}^{4}$ Capital Region of Denmark, Centre for Regional Development, Kongens Vænge 2, 3400 Hillerød, Denmark \\ ${ }^{5}$ Department of Geosciences and Nature Management, Univ. Copenhagen, Rolighedsvej 231958 Frederiksberg C, \\ Denmark. \\ ${ }^{6}$ University of Palermo, Department of Environmental Engineering and Territory, Piazza Marina, 61 - 90133 Palermo, \\ Italy.
}

Keywords: wetlands; nitrate reduction; organic matter; vertical distribution.

\begin{abstract}
The aim of the present study is to investigate the vertical distribution of the Nitrate Reduction Potential (NRP) at different depths on a natural (Evi site) and a re-stablished (Brynemade site) wetlands. The obtained NRP together with other environmental parameters provides a valuable data of the main driving factors affecting denitrification, the competitive process Dissimilatory Nitrate Reduction to Ammonium (DNRA) and the performance of a re-stablished wetland.

Intact soil cores (0-3 $\mathrm{m})$ were collected and were divided in $10 \mathrm{~cm}$ slices for the determination of Organic Matter (OM) through Loss of Ignition (LOI) as well as Dissolved Organic Carbon (DOC) and Nitrate Reduction Potential (NRP) spiking nitrate in batch tests. The nitrate reduction was fitted as a pseudo-first order rate constant ( $k$ ) from where NRPs were obtained.

Nitrate reduction took place in a very narrow superficial zone showing a dropping natural logarithmic trend along depth. The main driving factor of denitrification, besides depth, was OM. Although, DOC and LOI could not express by themselves and absolute correlation with NRP, high amounts of DOC ensured enough quantity and quality of labile organic matter for nitrate reduction. On the other hand, high concentration of recalcitrant LOI but a scarce abundance of DOC failed to drive nitrate reduction. DNRA showed to be important only in very superficial samples with high contents of $O M$. Lastly, the high nitrate reduction performance of the re-stablished wetland confirms that wetlands can be restored satisfactorily.
\end{abstract}

\section{Introduction}

Wetlands are examples of habitats that can be used directly to decrease nutrient loading of surface waters and to improve its quality. Nitrate Reduction (NR) in a riparian area is commonly attributed to denitrification, immobilization and plant uptake. [1,2] 
Specifically, denitrification is a biological process based on the biochemical reduction of nitrate and nitrite in groundwater thanks to the presence of anaerobe facultative bacteria in the site which can be autotrophic (if sulphur [3] or hydrogen [4] are present) or heterotrophic. In the latter case, electrons needed for nitrate reduction are originated from the oxidation of organic matter that also acts as a source of cellular carbon (heterotrophism). Illustrative, a stoichiometric reaction of a complete heterotrophic denitrification to nitrogen gas is presented in Equation 1 [5].

$$
5 \mathrm{CH}_{2} \mathrm{O}+4 \mathrm{NO}_{3}^{-} \rightarrow 2 \mathrm{~N}_{2}+4 \mathrm{HCO}_{3}^{-}+3 \mathrm{H}_{2} \mathrm{O}+\mathrm{CO}_{2}
$$

Riparian soils are rich in organic carbon substrate in top layers (Horizon O, e.g. Peat layer), that leaches dissolved Organic Matter (OM) which provides a carbon source to the heterotrophic denitrification pathway. In this way the age of the OM and the constant input of fresh OM from decayed vegetation is a key point for the process performance. The aging of $(\mathrm{OM})$ has an important influence on the denitrification through soil depth because the disappearance of labile fraction against horizons and time, limits the labile leachate that reaches deeper horizons. $[6,7]$

In addition, microorganisms are strongly influenced by environmental conditions: dissolved oxygen, mineralizable carbon, $\mathrm{pH}$, nutrients (e.g. phosphorus) [8, 9], water table elevation $[10,11]$, temperature and other seasonal conditions, [12]. All these conditions are critical for the denitrification process. Moreover, environmental conditions in Northern European countries where low temperatures (around $10{ }^{\circ} \mathrm{C}$ ) are common in groundwater might have a negative impact on denitrification performance since it is a temperature dependent process $[13,14]$.

Reported nitrate reduction rates ranged from 0.004 to $26.5 \mathrm{mg}$ nitrate $\cdot l^{-1} \cdot$ day $^{-1}$ [15] and first order constants were in the range $3 \cdot 10^{-5}$ to 1.4 day $^{-1}$ [16] for different types of vegetal-based materials and under different conditions.

Due to high environment heterogeneity in riparian soils, past studies of spatial distribution of the denitrification potential in these systems showed high variations in width and depth, [17-21]. In addition to previously exposed factors in riparian zones, variability can be caused by the great diversity of minerals and organic materials that can be found in different stratigraphic positions, due to sediment transport and settling mechanisms. These mechanisms are affected by frequency and duration of floods, flow patterns, stream velocity and distance from the main channel and eventually sediments could be flushed at one place and filled at another. [22]

Dissimilatory Nitrate Reduction to Ammonium (DNRA) could also be present. DNRA is a respiratory or fermentative pathway where nitrate is reduced step by step to ammonium competing with denitrification for the nitrate in groundwater [23] and in riparian zones [24], Equation 2.

$$
2 \mathrm{CH}_{2} \mathrm{O}+\mathrm{NO}_{3}^{-}+\mathrm{H}_{2} \mathrm{O} \rightarrow \mathrm{NH}_{4}^{+}+2 \mathrm{HCO}_{3}^{-} \quad \text { Eq. } 2
$$

Ammonium is retained in the soil until nitrification, plant uptake or anaerobic ammonium oxidation process occurs (Anammox). DNRA are less understood than denitrification although it can be a significant or even a dominant process in some ecosystems, [25]. Conditions favouring DNRA may include high temperature [26] and high $\mathrm{C} / \mathrm{N}$ ratio, [27]. It 
is believed, that heterotrophic denitrification supplies more free energy than DNRA, but under nitrate limiting conditions or high OM concentrations DNRA could be favoured because more electrons can be transferred per mole of nitrate, [28]. Notice that in both pathways nitrite is an intermediate.

In this work a lab-based methodology for the measurement of the Nitrate Reduction Potentials (NRP) on a natural and re-stablished wetlands at different depths is performed. The obtained NRP together with other environmental parameters provides a valuable data of the main factors affecting denitrification and the competitive process DNRA. It will validate the feasibility to restore wetlands with a working remediation role and assist the design of future re-stablished wetlands taking into account the key parameters affecting the denitrification performance.

\section{Materials and methods}

\section{Description of the sites}

Two Danish wetland field sites with an extremely similar geology and climate were selected for the present study. The Brynemade site (Odense river basin in Odense Island) has been chosen as a model of a well re-established wetland and the Evi site (Holtum river basin in Jutland, Western Denmark) as a model natural wetland-river system.

The two sites present a very similar geology, both are glacial flood plains composed by a first layer of freshwater deposits such as peat, organic silt, clay and sand followed by a deeper layer of sand and gravel deposited by glacial streams from the Weichsel glacial period. Sites were previously characterized in terms of geology by means of drilling and borehole logging. Several monitoring campaigns were performed after the sampling of the cores in order to compose their respective hydrogeological models and to acquire information about the groundwater chemistry. [29-31]

Brynemade wetland at the Odense river Basin (Denmark) $\left(55^{\circ} 13^{\prime} 12^{\prime \prime} \mathrm{N}, 10^{\circ} 17^{\prime} 35^{\prime \prime} \mathrm{E}\right.$; WGS84) was restored in 2003 and was used to document seasonal changes in flow dynamics and nitrate/pesticide degradation performance in a re-established wetland-river system. The restoration included re-raising the riverbed and re-meandering the river to the position it had prior to the 1958 channelization. The site is bordered by a Christmas tree plantation and crop land in the northern part.

The seasonal flow and transport of water and nitrates in this wetland was extensively modelled using hydrogeological characterization with wells, slug and infiltration tests, geophysical image of the subsurface using multi electrode profiling and measurements of the discharge to the river by seepage -meter and river bed temperature studies, [29]. From this modelling it was found that in non-flooding periods groundwater flow was horizontal from wetland to river. During flooding periods $(75 \%$ of the year) flow was upward through the peat layer. It was estimated that between 25 and $37 \%$ of the total groundwater was discharged through the peat. The main climate parameters were an annual mean temperature of $8.9^{\circ} \mathrm{C}$ and an annual accumulated precipitation of $733 \mathrm{~mm}$ (Years: 2001 to 2010, grid $20 \times 20 \mathrm{~km}$ for temperature and $10 \times 10 \mathrm{~km}$ for precipitation), [32]. 
Evi site is a natural wetland located close to Lake Ejstrup and the city of Ejstrupholm, in Jutland, (55'59'28' $\mathrm{N}, 9^{\circ} 19^{\prime} 43^{\prime}$ ' $\mathrm{E}$; WGS84). The catchment area is at the border of the maximum extension of the Weichselian glaciers corresponding to the last glacial advance. Unlike the Brynemade site, the Evi site is never flooded. Groundwater flow is strongly dependent on precipitations and no reverse flow from streambed to aquifer was observed, $[30,31]$. The main climate parameters were an annual mean temperature of $8.4^{\circ} \mathrm{C}$ and an annual accumulated precipitation of $860 \mathrm{~mm}$ (Years: 2001 to 2010 , grid 20x20 km for temperature and 10x10 km for precipitation), [32].

\section{Sampling of soil cores and characterization}

Two intact soil cores from Brynemade (B C.1 and B C.2, up to $3 \mathrm{~m}$ ) and Evi site (E C.1 up to $3 \mathrm{~m}$ and E C.2 up to $2 \mathrm{~m}$ ) were collected in May 2012 and May 2013, respectively. The soil cores were divided in slices of $10 \mathrm{~cm}$ in the laboratory and these subsamples were handled under anaerobic (nitrogen glove box) conditions for determination of NRP.

Moisture (M) was determined gravimetrically as the loss of mass after drying at $105^{\circ} \mathrm{C}$ overnight according to the method ISO 11465:1993 values were expressed in wet basis. Loss of Ignition (LOI) was calculated as the fraction of dry matter that was removed after 16 hours at $400{ }^{\circ} \mathrm{C}$ employing the standard method, [33].

Dissolved Organic Carbon (DOC) was determined at 1 hour batch experimental time and at the final of the test, the analyses were performed using a TOC analyzer (Multi N/C 3100) after being filtered through $0.2 \mu \mathrm{m}$ nylon filter, acidified with concentrated sulfuric acid and purged with synthetic air. These DOC values were used to estimate the initial concentration of DOC that could take part in nitrate reduction.

\section{NRP and DNRA of the soil cores}

Batch tests were used to study the kinetics of NRP in subsamples. $10 \mathrm{~g}$ of soil from each subsample was mixed with deionised water $(100 \mathrm{ml})$ and placed in $115 \mathrm{~mL}$ vials $(97 \mathrm{~mm}$ in height, $48 \mathrm{~mm}$ in diameter). Vials were sealed with butyl rubber septums. The culture was enriched up to $25 \mathrm{mg} \cdot \cdot^{-1}$ of nitrate supplied by sodium nitrate stock solution. All procedure was performed in a globe box in a nitrogen atmosphere. Tests were incubated at $10^{\circ} \mathrm{C}$ in a non-stirred system until nitrate depletion or up to 42 days. During incubation, water samples were withdrawn periodically through the septum and inside the globe box to analyse inorganic nitrogen species (nitrate, nitrite and ammonium).

Concentration of nitrogen species in batches were determined by ion chromatography (Dionex ICS-2100). In particular, nitrate and nitrite were analysed by using the column Ion pack AS19 4x250mm (quantification limit for both analytes of $1 \mathrm{mg} \cdot 1^{-1}$ ) and ammonium with the Ion pack CS16 4x250mm column (quantification limit of $0.2 \mathrm{mg} \cdot \mathrm{l}^{-1}$ ). Concentration of DOC was determined by high temperature catalytic combustion $-\mathrm{CO}_{2}$ NDIR-Detector. (Multi N/C 3100) (quantification limit of $0.2 \mathrm{mg} \cdot \mathrm{l}^{-1}$ ).

First-order nitrate reduction rate constants $(k)$ were determined by fitting the concentration results to Equation 3. Although the batches were analysed up to one month only the first days were considered in order to avoid side effects such as changes or contamination in 
microbial populations. Quantification limit of $k=0.01 \mathrm{~d}^{-1}$ was considered by using this method.

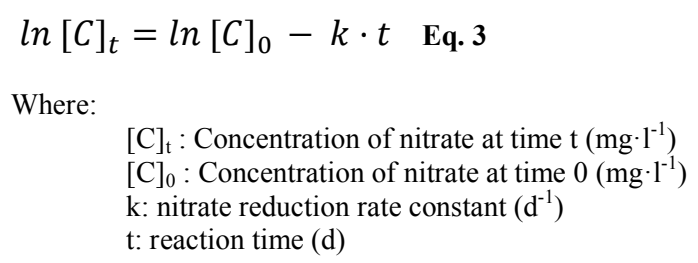

The generated data of $k$ and characterization values have been treated by XLSTAT 2015.1.01 Addinsoft ${ }^{\mathrm{TM}}$ in order to perform Pearson Matrices.

Ammonium and nitrite were analysed in some depths in order to assess DNRA importance. Both, denitrification and DNRA have a first parallel step where nitrate is reduced to nitrite, but the important difference to determine DNRA is if finally nitrogen is present as ammonium or as gaseous nitrogen, Equation 1 and 2.

\section{Results and Discussion}

\section{Characterization of cores}

Brynemade site

At Brynemade site, based on the measurements of multi electrode profiling [29], the wetland hydrogeology could be characterized by a three-layer system, i.e., an upper 1-2 m thick peat layer followed by an approximately 8-18 m thick heterogeneous sand aquifer, and a lower more silty/clayey layer of an undetermined thickness. This conceptual model has been confirmed by the following core characterization.

The LOI content of the cores showed a top $(0-100 \mathrm{~cm})$ rich peat layer, with values close to $90 \%$ in B C.1 and 70\% in B C.2., Figure 1. The deeper layers in B C.1 and B C.2 were inorganic, whereas in B C.2, the top peat was succeeded by a second layer $(100-140 \mathrm{~cm})$ of increased LOI content, averaging $13.8 \%(n=4)$.

Initial DOC, Figure 1, from lixiviates of B C.1 and B C.2 at 1 hour of running experiment presented high values in the upper part $(0-100 \mathrm{~cm})$ averaging 43.2 and $23.1 \mathrm{mg} \cdot \mathrm{l}^{-1}(\mathrm{n}=10$, each core) respectively following a decreasing in a saw-tooth trend.

Final DOC from lixiviates (results not shown) were higher than initial ones for upper layers and were lower for deeper layers in B C.1, pointing to the peat as an slow releasing source of DOC obstructing stoichiometric study of denitrification. Probably, an excess of DOC was present in upper layers and denitrification was not limited by the substrate, completing all the reduction of the spiked nitrate. In the case of B C.2, the DOC concentration did not change during the experiment in any of the depths. 
Moisture showed similar behaviour with a very humid peat layer (70-80\%) and deeper layers ranging between 10-20\%, Figure 1. In this case there was a more progressive transition than was the case of LOI which could be due to capillary effects.

Evi site

The LOI content of the cores from the Evi site (Figure 2) was very high. E C.1 had a relatively low concentration in the top layer (first $10 \mathrm{~cm}$ ) with $17.1 \%$ followed by high organic content layer from 40 to $160 \mathrm{~cm}$ in depth averaging $76.9 \%(n=13)$ then a saw-tooth trend to extinction was observed. In E C.2 transitions between organic layers and mineral layers were very marked with a very rich top layer $0-30 \mathrm{~cm}$ averaging $73.7 \%(\mathrm{n}=3)$ and other layer at $70-80 \mathrm{~cm}$ with $25.1 \%(\mathrm{n}=1)$.

Interestingly, initial DOC concentrations in both cores were very low in contrast to its LOI content, Figure 2. In E C.1 lixiviates were constant without a trend to extinction with depth, averaging $14.7 \mathrm{mg} \cdot \mathrm{l}^{-1}$ in all samples $(\mathrm{n}=29)$. Contrarily, E C.2 averaged very low concentrations. A sharp DOC decrease with depth was observed, from the upper $20 \mathrm{~cm}$ with a $18.3 \mathrm{mg} \cdot 1^{-1}$ to a base level of $3 \mathrm{mg} \cdot 1^{-1}$. These values were appreciably lower than in the Brynemade site. No important DOC evolution was observed at the end of the experiment matching with the poor NRP observed.

Moisture values, such as those observed in Brynemade, were in accordance to LOI values, but in Evi the moisture was much lower than in Brynemade with an organic layer (more than $10 \%$ ) and deeper layers less than 10\% moisture, Figure 2. As in Brynemade, the different materials suppose different moisture that could be linked to field capacity as deep levels were saturated with water.

\section{Nitrate reduction potential results}

The nitrate concentration data in NRP experiments were fitted to Equation 3 model. Examples of the fitting are shown in Figure 3. As it can be observed, nitrate reduction was explained as a pseudo first-order constant in the first days which is in agreement with the literature, [34]. Finally the lack of proper DOC for the nitrate reduction or the kinetic quantification limit of the technique restricted the application of the first-order model. Despite the low incubation temperature $\left(10^{\circ} \mathrm{C}\right)$ used in order to simulate field conditions, high NRP were observed.

At Brynemade site, high NRPs were found in the upper part of the cores $<30 \mathrm{~cm}$ (Figure 1) that also showed high concentrations of LOI and DOC $<70 \mathrm{~cm}$. In this zone high first-order rate constants were achieved, reaching $1.43 \mathrm{~d}^{-1}$ B C. 1 and $1.49 \mathrm{~d}^{-1}$ B C. 2 in the top (0-10 $\mathrm{cm})$, then kinetics decreased exponentially with depth. Into these first $30 \mathrm{~cm}$ of soil NRP averaged $1.05 \mathrm{~d}^{-1}(\mathrm{n}=3)$ B C.1 and $0.70(n=3) \mathrm{d}^{-1}$ B C.2. The high NRPs and rich OM zone was succeeded by a lower NRP and OM zone, nitrate reduction was undetectable, considered as $0.01 \mathrm{~d}^{-1}$, in many samples under $70 \mathrm{~cm}$ depth and in most samples under 130 $\mathrm{cm}$ depth giving an overall mean of $0.14 \mathrm{~d}^{-1}(\mathrm{n}=31) 0$ to $310 \mathrm{~cm} \mathrm{~B} \mathrm{C.1} \mathrm{and} 0.14 \mathrm{~d}^{-1}(\mathrm{n}=31) 0$ to $320 \mathrm{~cm} \mathrm{~B} \mathrm{C.2.} \mathrm{A} \mathrm{remarkably} \mathrm{exception} \mathrm{in} \mathrm{B} \mathrm{C.2} \mathrm{at} 130-140 \mathrm{~cm}$ depth with $0.63 \mathrm{~d}^{-1}$ was found. Samples from below $315 \mathrm{~cm}$ would probably also be below the detection limit of $0.01 \mathrm{~d}^{-1}$. In addition, DOC was probably recalcitrant compared to the top layers because rate constants were negligible. The origin of this recalcitrant DOC in the cores was unlikely to 
come from the sand and possible came from upper layers where the labile OM for nitrate reduction has been consumed.

The Evi site showed a poor nitrate reduction potential in both cores in spite of high LOI content, even in the top zone of the soil $(0-10 \mathrm{~cm})$ being $0.11 \mathrm{~d}^{-1}$ E C.1 and $0.18 \mathrm{~d}^{-1}$ E C.2, respectively. The averages for the first $30 \mathrm{~cm}$ were: $0.09 \mathrm{~d}^{-1}(n=3)$ in E C.1 and $0.11(n=3) \mathrm{d}^{-}$

${ }^{1}$ in E C.2. Then NRP followed a quickly trend to extinction also in E C.1 which presented a very high LOI content from 30 to $170 \mathrm{~cm}$. Global means were $0.04 \mathrm{~d}^{-1}(\mathrm{n}=29) 0$ to $300 \mathrm{~cm}$ in E C. 1 and $0.03 \mathrm{~d}^{-1}(\mathrm{n}=20) 0$ to $200 \mathrm{~cm}$ in E C.2, Figure 2.

\section{Link of NRP to environmental parameters}

Cores from the same sites had a similar behaviour in NRP and had similar environmental parameters. Statistical analysis was performed merging the data from both cores of each site in order to unveil relevant correlations between the main parameters involved in the NRP.

The Pearson Matrix (PM) Table 1 (Brynemade) and 2 (Evi) produces the correlation coefficients between all the couples of variables. This matrix has been extended by adding the natural logarithm of the measured variables to test linear, exponential and potential fitting models. For all these correlation studies, significance levels of $5 \%$ and $1 \%$ were calculated.

From Table 1, all correlations in Brynemade exceeded 1\% of significance level and showed a strong correlation between parameters. The most important correlations were the anticorrelations of soil depth (z) vs: $\ln k$, ln LOI, $\ln$ DOC and M demonstrating a natural logarithmic extinction through soil depth. It was also observed that $k$, LOI, DOC and $\mathrm{M}$ were positive and strongly correlated.

The most important correlation found in Evi's PM, Table 2, were $k$ vs $\ln \mathrm{z}$. As in Brynemade all the measured parameters decrease with z. In parallel, only DOC-LOI, $k$-DOC, DOC-LOI and LOI-M correlations were significant.

From statistical analysis, it was observed that the most relevant driving factors for $k$ in Brynemade were $\ln \mathrm{z}$ and OM and in Evi ln $\mathrm{z}$.

The link between NRP and OM (LOI and DOC) was only significant in the Brynemade site. In the Evi site NRP was lower than in Brynemade with high amounts of LOI but low DOC. This means that in this case the quality of the $\mathrm{OM}$ is more important than the quantity as stated in previous cases. [35-38]

In order to compare the trends of $k$ values with $\mathrm{z}$, Table 3 shows the fitting of $k$ vs $\ln \mathrm{z}$ that was the best empirical correlation that fitted the trend of $k$ measurements with $\mathrm{z}$. As it can be seen, Brynemade showed much higher initial values of $k$ (intercept is $k$ value for $1 \mathrm{~cm}$ ) with higher decreasing trend compared to Evi values.

\section{DNRA Evaluation}


DNRA evaluation was performed from the measurement of the increment of ammonium that is shown in Table 4.

As is seen in Table 4, B C.1 and B C. 2 between $0-10 \mathrm{~cm}$ depth accumulated an important amount of ammonium. Nitrite in the same samples was negligible, with maximum increasing values of $1 \mathrm{mg}$ nitrite $\mathrm{l}^{-1}$ in core B C.2 at $25 \mathrm{~cm}$ and without increase for cores B C.1, E C.1 and E C.2.

Taking into account that the nitrogen contained in an ammonium concentration of $7.2 \mathrm{mg} \cdot \mathrm{l}^{-1}$ is equal to $25 \mathrm{mg} \cdot \mathrm{l}^{-1}$ of nitrate (spiked initial concentration), the following expression could be used to evaluate the fraction of DNRA, Equation 4. Table 5 shows the results of DNRA fraction.

$$
\begin{aligned}
& f_{D N R A}=-3,472 \frac{\Delta\left[\mathrm{NH}_{4}^{+}\right]}{\Delta C} \quad \text { Eq. } 4 \\
& \text { Where: } \\
& \qquad \begin{array}{l}
f_{D N R A}, \text { DNRA fraction } \\
\Delta\left[\mathrm{NH}_{4}^{+}\right] \text {is the increment with time of ammonium concentration }\left(\mathrm{mg} \cdot \mathrm{l}^{-1}\right) \\
\Delta \mathrm{C} \text { is the variation in time of nitrate }\left(\mathrm{mg} \cdot \mathrm{l}^{-1}\right) \text { measured in the same points. }
\end{array}
\end{aligned}
$$

As is seen in Table 5 the fraction of DNRA was only significant in the first $10 \mathrm{~cm}$ of Brynemade cores (between 43 and 50\% in B C.2 and B C.1, respectively). Contrarily, at the Evi site, the DNRA activity was only important between 20 and $30 \mathrm{~cm}$ at E C.1, other samples always showed a DNRA fraction below $1 \%$. These results could be explained by the high superficial concentration of organic matter that favours DNRA pathway.

\section{Conclusions}

Nitrate reduction took place in a very narrow superficial zone showing a natural logarithmic decrease to extinction, hence being undetectable in the deepest samples. In addition, it is worth mentioning that nitrate reduction followed a pseudo first-order constant.

DOC and LOI couldnot express by themselves an absolute correlation with NRP, but high amounts of DOC during the experiments ensured enough quantity of labile organic matter for nitrate reduction. On the other hand, low concentrations of DOC even in a rich LOI soil presented low NRPs, strengthening the idea that labile OM (quality) is more important that quantity.

DNRA was only important in the very superficial samples of Brynemade, where a high content of labile OM could produce favourable conditions for DNRA.

Wetlands can be restored satisfactorily concerning nitrate reduction performance. Comparing a natural wetland (Evi) to the re-stablished (Brynemade) with a similar geology and climate and taking into consideration the high NRPs observed in the latter, it is clear that other factors besides the re-stablishing condition play a more important role.

\section{Acknowledgments}


This work was funded by: the EU-project AQUAREHAB (FP7 - Grant Agreement Nr. 226565); the Spanish Ministry of Economy and Competitivity through project ATTENUATION (CGL2011-29975-C04-03, Natural and Induced Attenuation of groundwater pollution from agricultural and industrial sources) and D Ribas is supported by Spanish Ministry of Economy and Competitiveness, under the FPI grant (ref. BES-2012-052327).

\section{References}

1. Haycock NE, Pinay G, Walker C. Nitrogen retention in river corridors: European Perspective. Ambio. 1993;22(6):340-346.

2. Mayer PM, Canfield TJ, McCutchen MD, Reynolds SKJ. Meta-Analysis of Nitrogen Removal in Riparian Buffers. J Environ Qual. 2007;36(4):1172-1180.

3. Komor A, Fox P. Evaluation of denitrification rates and mechanisms in microcosm experiments with sediments and plants. Proceedings of the Water Environment Federation, 2002(16), 496-514.

4. Smith RL, Ceazan ML, Brooks MH. Autotrophic, hydrogen-oxidizing, denitrifying bacteria in groundwater, potential agents for bioremediation of nitrate contamination. Appl Environ Microbiol. 1994;60(6):1949-1955.

5. Jørgensen PR, Urup J, Helstrup T, Jensen MB, Eiland F, Vinther FP. Transport and reduction of nitrate in clayey till underneath forest and arable land. J Contam Hydrol. 2004;73(1-4):207-226.

6. Choi Y, Wang Y. Dynamics of carbon sequestration in a coastal wetland using radiocarbon measurements. Global Biogeochem Cycles. 2004;18(4):1-12.

7. Strosser E. Methods for determination of labile soil organic matter: an overview. J Agrobiol. 2010;27(2):49-60.

8. Pfenning KS, McMahon PB. Effect of nitrate, organic carbon, and temperature on potential denitrification rates in nitrate-rich riverbed sediments. J Hydrol. 1997;187(3-4):283-295.

9. Song K, Kang H, Zhang L, Mitsch WJ. Seasonal and spatial variations of denitrification and denitrifying bacterial community structure in created riverine wetlands. Ecol Eng. 2012;38(1):130-134.

10. Hefting M, Clément JC, Dowrick D, et al. Water table elevation controls on soil nitrogen cycling in riparian wetlands along a European climatic gradient. Biogeochemistry. 2004;67(1):113-134.

11. Hernandez ME, Mitsch WJ. Denitrification in created riverine wetlands: Influence of hydrology and season. Ecol Eng. 2007;30(1):78-88.

12. Ribas D, Calderer M, Martí V, Rovira M. Effect of different seasonal conditions on the potential of wetland soils for groundwater denitrification. Desalin Water Treat. 2013;53(4):1-7.

13. Brüsch W, Nilsson B. Nitrate transformation and water movement in a wetland area. Hydrobiologia. 1993;251(1-3):103-111.

14. Rivett MO, Buss SR, Morgan P, Smith JWN, Bemment CD. Nitrate attenuation in groundwater: A review of biogeochemical controlling processes. Water Res. 2008;42(16):4215-4232.

15. Gibert O, Pomierny S, Rowe I, Kalin RM. Selection of organic substrates as potential reactive materials for use in a denitrification permeable reactive barrier (PRB). Bioresour Technol. 2008;99(16):7587-7596.

16. Leverenz HL, Haunschild K, Hopes G, Tchobanoglous G, Darby JL. Anoxic treatment wetlands for denitrification. Ecol Eng. 2010;36(11):1544-1551. 
17. Cosandey AC, Guenat C, Bouzelboudjen M, Mattre V, Bovier R. The modelling of soil-process functional units based on three-dimensional soil horizon cartography, with an example of denitrification in a riparian zone. Geoderma. 2003;112(1), 111-129.

18. Curie F, Ducharne A, Bendjoudi H, Billen G. Spatialization of denitrification by river corridors in regional-scale watersheds: Case study of the Seine river basin. Physics and Chemistry of the Earth, Parts A/B/C, 2011;36(12), 530-538.

19. Hayakawa A, Nakata M, Jiang R, Kuramochi K, Hatano R. Spatial variation of denitrification potential of grassland, windbreak forest, and riparian forest soils in an agricultural catchment in eastern Hokkaido, Japan. Ecol Eng. 2012;47:92-100.

20. Kjellin J, Hallin S, Wörman A. Spatial variations in denitrification activity in wetland sediments explained by hydrology and denitrifying community structure. Water Res. 2007;41(20):47104720.

21. Oehler F, Bordenave P, Durand P. Variations of denitrification in a farming catchment area. Agric Ecosyst Environ. 2007;120(2-4):313-324.

22. Asselman NEM, Middelkoop H. Floodplain sedimentation: quantities, patterns and processes. Earth Surf Process Landforms. 1995;20(1 995):481-499.

23. Calderer M, Gibert O, Martí V, Rovira M, de Pablo J, Jordana S, Duro L, Guimerà J, Bruno J. Denitrification in presence of acetate and glucose for bioremediation of nitrate-contaminated groundwater. Environmental Technology, 2010;31 799-814.

24. Sgouridis F, Heppell CM, Wharton G, Lansdown K, Trimmer M. Denitrification and dissimilatory nitrate reduction to ammonium (DNRA) in a temperate re-connected floodplain. Water Res. 2011;45(16):4909-4922.

25. Rütting T, Boeckx P, Müller C, Klemedtsson L. Assessment of the importance of dissimilatory nitrate reduction to ammonium for the terrestrial nitrogen cycle. Biogeosciences, 2011;8(7), 17791791.

26. Chen Z, Wang C, Gschwendtner S, et al. Relationships between denitrification gene expression, dissimilatory nitrate reduction to ammonium and nitrous oxide and dinitrogen production in montane grassland soils. Soil Biol Biochem. 2015;87:67-77.

27. Kraft B, Tegetmeyer HE, Sharma R, et al. The environmental controls that govern the end product of bacterial nitrate respiration Supplements. Science (80- ). 2014;345(6197):676-679.

28. Kraft B, Strous M, Tegetmeyer HE. Microbial nitrate respiration - Genes, enzymes and environmental distribution. J Biotechnol. 2011;155(1):104-117.

29. Jensen JK. Flow and transport in riparian zones Ph. D. Thesis. Copenhagen: University of Copenhagen; 2014.

30. Poulsen JB, Sebok E, Duque C, Tetzlaff D, Engesgaard PK. Detecting groundwater discharge dynamics from point to catchment scale in a lowland stream: combining hydraulic and tracer methods. Hydrology and Earth System Sciences Discussions, 2014;11(12), 13101-13143.

31. Sebok E, Duque C, Engesgaard P, Boegh E. Application of Distributed Temperature Sensing for coupled mapping of sedimentation processes and spatio-temporal variability of groundwater discharge in soft-bedded streams. Hydrological Processes, 2015;29(15), 3408-3422.

32. Riddersholm WP. Teknisk Rapport 13-09, Klimagrid Danmark, Referenceværdier 2001-2010. Danish Meteorological Institute; 2013.

33. Nelson DW, Sommers LE. Total carbon, organic carbon, and organic matter. In: Methods of Soil Analysis, Part 2, 2nd ed., A.L. Page et al., Ed. Agronomy. 9:961-1010. Am. Soc. of Agron., Inc. Madison, WI; 1996. 
34. Heinen M. Simplified denitrification models: Overview and properties. Geoderma. 2006;133(34):444-463.

35. Bastviken SK, Eriksson PG, Premrov A, Tonderski K. Potential denitrification in wetland sediments with different plant species detritus. Ecol Eng. 2005;25(2):183-190.

36. Dodla SK, Wang JJ, DeLaune RD, Cook RL. Denitrification potential and its relation to organic carbon quality in three coastal wetland soils. Sci Total Environ. 2008;407(1):471-480.

37. Hill AR, Cardaci M. Denitrification and Organic Carbon Availability in Riparian Wetland Soils and Subsurface Sediments. Soil Sci Soc Am J. 2004;68(1):320.

38. Hume NP, Fleming MS, Horne AJ. Plant carbohydrate limitation on nitrate reduction in wetland microcosms. Water Res. 2002;36(3):577-584. 


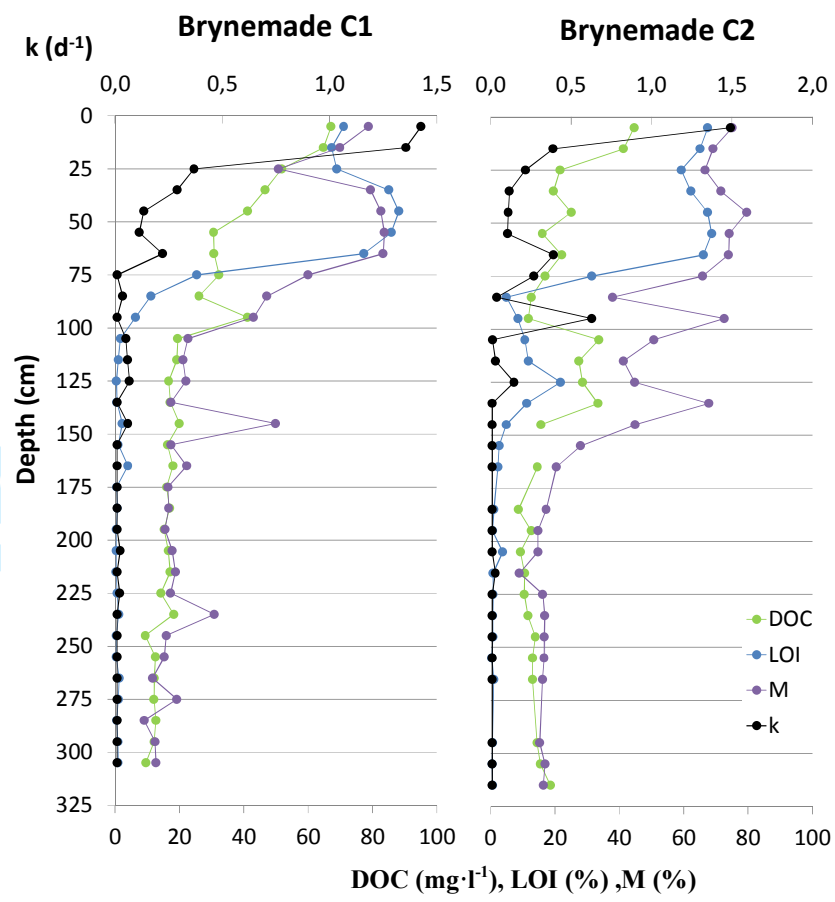

Figure 1. Depth-dependence of soil organic matter determined as DOC and LOI, soil moisture (M) and first-order nitrate reduction rate constants $(k)$ at the Brynemade cores. 


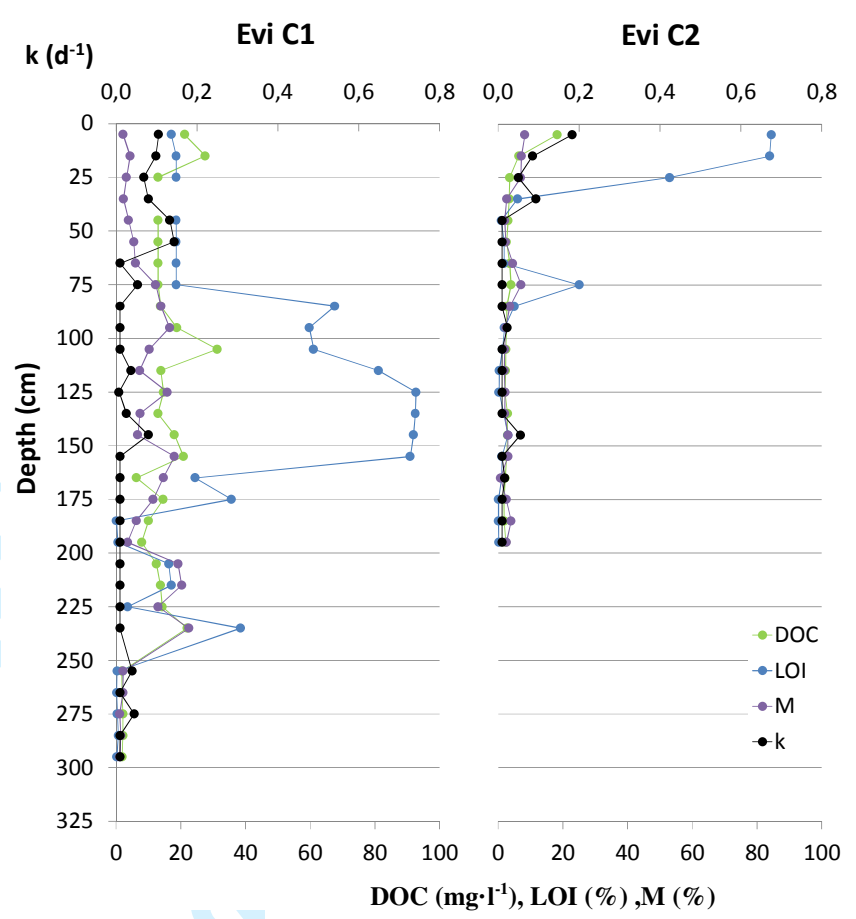

Figure 2. Depth-dependence of soil organic matter determined as DOC, LOI, soil moisture (M) and first-order nitrate reduction rate constants $(k)$ at Evi Cores. 


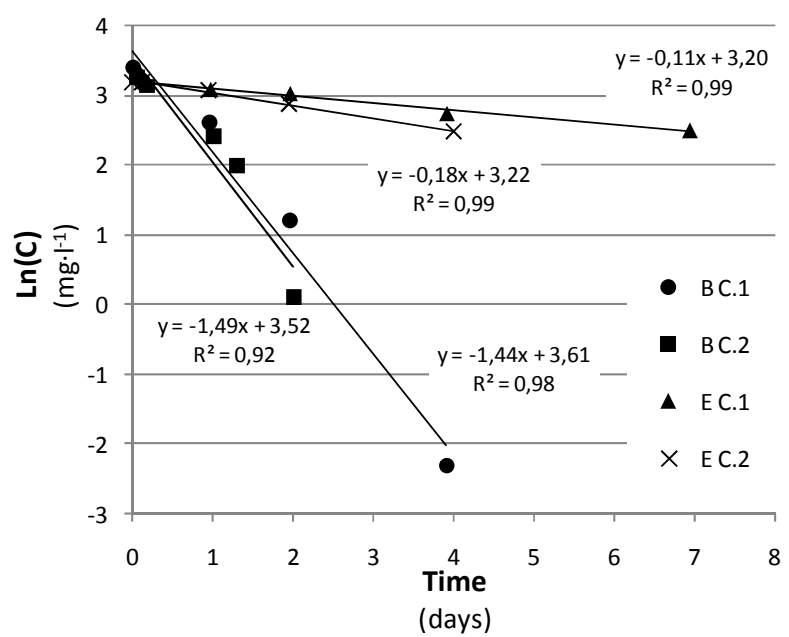

Figure 3. Kinetics fittings of first-order kinetics for $0-10 \mathrm{~cm}$ depth of Brynemade C.1 and C.2, Evi C1 and C.2. 
Table 1. Matrix of Pearson correlation coefficients of Brynemade site Core 1 and 2 processed jointly, a statistical significance at the level of $5 \%$ is indicated in* and at the level of $1 \%$ in**. $n=60$.

\begin{tabular}{|c|c|c|c|c|c|c|c|c|c|c|}
\hline Variables & $\mathrm{z}$ & $\mathrm{k}$ & LOI & DOC & $\mathrm{M}$ & $\ln \mathrm{z}$ & Ln k & ln LOI & $\ln \mathrm{DOC}$ & $\operatorname{Ln} M$ \\
\hline $\mathrm{z}$ & 1,00 & & & & & & & & & \\
\hline $\mathrm{k}$ & $-0,55^{* *}$ & 1,00 & & & & & & & & \\
\hline LOI & $-0,78^{* *}$ & $0,57^{* *}$ & 1,00 & & & & & & & \\
\hline DOC & $-0,70^{* *}$ & $0,71^{* *}$ & $0,71^{* *}$ & 1,00 & & & & & & \\
\hline M & $-0,86^{* *}$ & $0,55^{* *}$ & $0,88^{* *}$ & $0,68^{* *}$ & 1,00 & & & & & \\
\hline $\ln z$ & & $-0,80^{* *}$ & $-0,83^{* *}$ & $-0,82^{* *}$ & $-0,81^{* *}$ & 1,00 & & & & \\
\hline $\ln \mathrm{k}$ & $-0,80^{* *}$ & & $0,81^{* *}$ & $0,67^{* *}$ & $0,80^{* *}$ & $-0,87^{* *}$ & 1,00 & & & \\
\hline $\ln \mathrm{LOI}$ & $-0,87^{* *}$ & $0,54^{* *}$ & & $0,71^{* *}$ & $0,94^{* *}$ & $-0,84^{* *}$ & $0,79^{* *}$ & 1,00 & & \\
\hline $\ln \mathrm{DOC}$ & $-0,75^{* *}$ & $0,60^{* *}$ & $0,71^{* *}$ & & $0,73^{* *}$ & $-0,79^{* *}$ & $0,65^{* *}$ & $0,74^{* *}$ & 1,00 & \\
\hline $\ln \mathrm{M}$ & $-0,88^{* *}$ & $0,51^{* *}$ & $0,81^{* *}$ & $0,69 * *$ & & $-0,80^{* *}$ & $0,76^{* *}$ & $0,92^{* *}$ & $0,75^{* *}$ & 1,00 \\
\hline
\end{tabular}


Table 2. Matrix of Pearson correlation coefficients of Evi site Core 1 and 2 processed jointly, a statistical significance at the level of $5 \%$ is indicated in* and at the level of $1 \%$ in**. $n=49$.

\begin{tabular}{|c|c|c|c|c|c|c|c|c|c|c|}
\hline Variables & $\mathrm{z}$ & $\mathrm{k}$ & LOI & DOC & M & $\ln z$ & Ln k & $\operatorname{lnLOI}$ & $\ln \mathrm{DOC}$ & Ln M \\
\hline $\mathrm{z}$ & 1,00 & & & & & & & & & \\
\hline $\mathrm{k}$ & $-0,53^{* *}$ & 1,00 & & & & & & & & \\
\hline LOI & $-0,28$ & 0,24 & 1,00 & & & & & & & \\
\hline DOC & $-0,26$ & $0,31 *$ & $0,60^{* *}$ & 1,00 & & & & & & \\
\hline M & 0,10 & $-0,15$ & $0,53^{* *}$ & $0,60 * *$ & 1,00 & & & & & \\
\hline $\ln \mathrm{z}$ & & $-0,72^{* *}$ & $-0,26$ & $-0,31^{*}$ & 0,14 & 1,00 & & & & \\
\hline $\ln \mathrm{k}$ & $-0,50 * *$ & & 0,23 & 0,25 & $-0,21$ & $-0,66^{* *}$ & 1,00 & & & \\
\hline ln LOI & $-0,49^{* *}$ & $0,36^{*}$ & & $0,70^{* *}$ & $0,62^{* *}$ & $-0,43^{* *}$ & $0,35^{*}$ & 1,00 & & \\
\hline $\ln \mathrm{DOC}$ & $-0,31^{*}$ & $0,33^{*}$ & $0,64^{* *}$ & & $0,67^{* *}$ & $-0,33^{*}$ & 0,27 & $0,79^{* *}$ & 1,00 & \\
\hline $\ln \mathrm{M}$ & $-0,10$ & $-0,02$ & $0,62^{* *}$ & $0,65^{* *}$ & & $-0,02$ & $-0,09$ & $0,71^{* *}$ & $0,75^{* *}$ & 1,00 \\
\hline
\end{tabular}

13

14

15

16

17

18

19

20

21

22

23

24

25

26

27

28

29

30

31

32

33

34

35

36

37

38

39

40

41

42

43

44

45

46

47

48

49

50

51

52

53

54

55

56

57

58

59

60

URL: http:/mc.manuscriptcentral.com/tent 
Table 3. Nitrate reduction potential first-order kinetic constants $(k)$ along depth fitted in natural logarithmic regressions. B (Brynemade), E (Evi), C (Core) and (n). z in $\mathrm{cm}$.

\begin{tabular}{c|c|c|c}
\hline \multicolumn{2}{c|}{ Brynemade wetland } & \multicolumn{2}{c}{ Evi wetland } \\
\hline$k$ B.C1 $\left(\mathrm{d}^{-1}\right)$ & $k$ B.C2 $\left(\mathrm{d}^{-1}\right)$ & $k \mathrm{E} \cdot \mathrm{C} 1\left(\mathrm{~d}^{-1}\right)$ & $k \mathrm{E} \cdot \mathrm{C} 2\left(\mathrm{~d}^{-1}\right)$ \\
\hline$-0.30 \cdot \ln (\mathrm{z})+1.570$ & $-0.23 \cdot \ln (\mathrm{z})+1.241$ & $-0.02 \cdot \ln (\mathrm{z})+0.174$ & $-0.03 \cdot \ln (\mathrm{z})+0.198$ \\
$\mathrm{R}^{2}=0.71$ & $\mathrm{R}^{2}=0.58$ & $\mathrm{R}^{2}=0.48$ & $\mathrm{R}^{2}=0.69$ \\
$(31)$ & $(29)$ & $(29)$ & $(20)$ \\
\hline
\end{tabular}


Table 4.Measurements of ammonium $\left(\mathrm{mg} \cdot \mathrm{l}^{-1}\right)$ at the beginning $(1 \mathrm{~h})$ and at the end of nitrate reduction experiments.

\begin{tabular}{r|cc|cc|cc|cc}
\hline \multicolumn{1}{c}{} & \multicolumn{2}{c}{ B C1 } & \multicolumn{2}{c}{ B C2 } & \multicolumn{2}{c}{ E C1 } & \multicolumn{2}{c}{ E C2 } \\
Depth & Initial & Final & Initial & Final & Initial & Final & Initial & Final \\
$0-10$ & 1.8 & 6.0 & 3.0 & 6.2 & 0.6 & 0.9 & 0.5 & 0.8 \\
$20-30$ & 0.6 & 1.0 & 0.6 & 1.0 & 0.3 & 0.7 & $<0.2$ & $<0.2$ \\
$40-50$ & 0.4 & 0.2 & 0.2 & 0.2 & 0.3 & 0.4 & $<0.2$ & $<0.2$ \\
$180-190$ & $<0.2$ & $<0.2$ & $<0.2$ & $<0.2$ & n.a. & n.a. & n.a. & n.a. \\
\hline
\end{tabular}

n.a. not available 
Table 5. Measurement of fDNRA in reduction experiments.

\begin{tabular}{r|c|c|c|c}
\hline \multicolumn{1}{c}{ Depth } & B C.1 & B C.2 & E C.1 & E C.2 \\
$0-10$ & 0.50 & 0.43 & 0.04 & 0.04 \\
$20-30$ & 0.05 & 0.06 & 0.12 & $<0.01$ \\
$40-50$ & $<0.01$ & $<0.01$ & 0.01 & $<0.01$ \\
$180-190$ & n.a.* & $<0.01$ & n.a. & n.a. \\
\hline *n.a. not available
\end{tabular}

UR: http./mc.manuscriptcentral.com/tent 